\title{
The Effects from DNA Extraction Methods on the Evaluation of Microbial Diversity Associated with Human Colonic Tissue
}

\author{
Páraic Ó Cuív • Daniel Aguirre de Cárcer • Michelle Jones • Eline S. Klaassens • \\ Daniel L. Worthley • Vicki L. J. Whitehall • Seungha Kang • \\ Christopher S. McSweeney • Barbara A. Leggett • Mark Morrison
}

Received: 27 May 2010 / Accepted: 2 November 2010 /Published online: 14 December 2010

(C) Scientific \& Industrial Research Organisation 2010

\begin{abstract}
Potentially valuable sources of DNA have been extracted from human colonic tissues and are retained in biobanks throughout the world, and might be re-examined to better understand host-microbe interactions in health and disease. However, the published protocols for DNA extraction typically used by gastroenterologists have not been systematically compared in terms of their recovery of the microbial fraction associated with colonic tissue. For this reason, we examined how three different tissue DNA extraction methods (the QIAGEN AllPrep DNA/RNA kit, salting out and high molecular weight (HMW) methods of DNA extraction) employed in past clinical trials, and the repeated bead beating and column $(\mathrm{RBB}+\mathrm{C})$ method might impact the recovery of microbial DNA from colonic tissue, using a custom designed phylogenetic microarray for gut
\end{abstract}

P. Ó Cuív · D. Aguirre de Cárcer · M. Jones · E. S. Klaassens •

S. Kang $\cdot$ C. S. McSweeney $\cdot$ M. Morrison $(\bowtie)$

CSIRO Preventative Health Flagship Research Program

and Division of Livestock Industries,

Queensland Biosciences Precinct,

306 Carmody Road,

Queensland 4067, Australia

e-mail: mark.morrison@csiro.au

P. Ó Cuív

e-mail: paraic.ocuiv@csiro.au

D. L. Worthley • V. L. J. Whitehall • B. A. Leggett

The Conjoint Gastroenterology Laboratory, Royal Brisbane

and Women's Hospital Foundation Clinical Research Centre

and the Queensland Institute of Medical Research,

Queensland 4029, Australia

M. Morrison

The Ohio State University,

Columbus, OH, USA bacteria and archaea. All four methods produced very similar profiles of the microbial diversity, but there were some differences in probe signal intensities, with the HMW method producing stronger probe intensities for a subset of the Firmicutes probes including Clostridium and Streptococcus spp. Real-time PCR analysis revealed that the HMW and $\mathrm{RBB}+\mathrm{C}$ extracted DNA contained significantly more DNA of Firmicutes origin and that the different DNA extraction methods also gave variable results in terms of host DNA recovery. All of the methods tested recovered DNA from the archaeal community although there were some differences in probe signal intensity. Based on these findings, we conclude that while all four methods are efficacious at releasing microbial DNA from biopsy tissue samples, the HMW and $\mathrm{RBB}+\mathrm{C}$ methods of DNA extraction may release more DNA from some of the Firmicutes bacteria associated with colonic tissue. Thus, DNA archived in biobanks could be suitable for retrospective profiling analyses, provided the caveats with respect to the DNA extraction method(s) used are taken into account.

\section{Introduction}

The microbiome resident in the human large intestine is now widely recognised to provide a variety of physiological and ecological functions relevant to host nutrition and wellbeing $[2,18]$. Furthermore, the gut microbiome has been shown to undergo some dramatic structural changes in obese and overweight subjects [54, 55], as well as in persons diagnosed with inflammatory bowel diseases $[6,7$, 57] or colorectal cancer [18, 49]. Much still remains to be learned about the cause-effect relationships of microbiome alteration and disease, as well as whether such information 
can be used for risk stratification and/or clinical management of disease.

Microbial diversity in environmental samples has traditionally been assessed by low throughput polymerase chain reaction (PCR)-based profiling methods such as the analysis of terminal restriction fragment length polymorphisms (T-RFLP), denaturing gradient gel electrophoresis (DGGE), or by the analysis of rRNA ( $r r s$ ) gene clone libraries. Despite method-specific and PCR-based biases (e.g. primer selection and PCR amplification bias) these methodologies have been widely applied due to their relative simplicity and robustness. Of these methods, the analysis of rrs clone libraries has been considered the "gold standard"; however, this method becomes increasingly laborious when complex communities or multiple samples are processed. This is mainly due to the time-consuming nature of the technique and the costly method of Sanger DNA sequencing needed to provide precise taxonomic assignment and coverage of the microbial community. Conversely, both phylogenetic microarrays and nextgeneration sequencing technologies now offer an efficient, high throughput and affordable alternative to characterise microbial diversity. These methods however are also prone to PCR-based biases in addition to having their own specific limitations. Phylogenetic microarrays require prior information on community composition to facilitate probe design and microarrays are consequently incapable of identifying members of the community unless the appropriate probes are present. Moreover, poor probe design and/ or non-specific hybridisation(s) can lead to erroneous determinations of microbial diversity. In contrast, nextgeneration sequencing is susceptible to overestimating microbial diversity due to inherent difficulties in accurately sequencing DNA homopolymer repeat regions [23, 46]. This and the volume of sequences produced necessitate the use of specialist software to process and analyse the resultant data (e.g. [8, 45, 51]). Nonetheless, both technologies continue to be widely adopted due to their ability to rapidly and sensitively profile microbial communities in large numbers of complex samples.

DNA extraction is a key factor affecting any approach for analysing microbial diversity. Numerous methods have been described for the isolation of microbial DNA from human stool samples, and like other fields of microbial ecology, mechanical lysis by bead beating tends to be favoured as such methods have been shown to be most effective at capturing the microbial diversity (e.g. [13, 28, $37,48,59])$. In that context, the repeated bead-beating and column purification method $(\mathrm{RBB}+\mathrm{C})$ first described by $\mathrm{Yu}$ and Morrison [58] has recently been shown by Salonen et al. [48] to produce superior results in terms of DNA yield and recovery of phylogenetic diversity from human stool samples. In contrast, there does not yet appear to have been a systematic assessment of how different DNA extraction methods might influence the appraisal of the microbiome adherent to the colonic mucosa. This remains an important issue because several studies have shown that the mucosal and faecal associated microbiota differ (e.g. [14, 27, 41, $60])$. These differences might be relevant to better understanding the role of the gut microbiota in human health and disease because in contrast to faecal samples, the colonic tissue and its associated microbial microenvironment can be sampled from where disease is manifestly apparent.

There are many clinical biobanks that contain DNA samples prepared from healthy and diseased colonic tissues that may prove to be extremely valuable for microbiological profiling. Unfortunately, the DNA extraction methods used by clinicians do vary, both from clinic-to-clinic, as well as from those used typically by environmental microbiologists and microbial ecologists. In particular, the nucleic acid extraction methods that have traditionally been employed by clinicians with colonic tissue: viz. the high molecular weight and salting out methods described by Marmur [30] and Miller et al. [35], respectively; and more recently, the QIAGEN AllPrep DNA/RNA kit for nucleic acid extraction, do not employ a bead-beating step. These methods were/are primarily used to recover host DNA/ RNA and often without the anticipation that the same samples might also be analysed with respect to gut microbiome structure-function relationships. In particular, these DNA samples could facilitate powerful crosssectional and inception-based studies of microbiome structure that might add to the host-based measurements already collected and published; if it can first be confirmed that microbial DNA was also effectively released by the DNA extraction methods typically (or historically) used with colonic tissue samples.

With this background, the aim of this study was to evaluate how well the DNA extraction methods routinely used by gastroenterologists compare with the $\mathrm{RBB}+\mathrm{C}$ protocol in revealing the microbial diversity associated with colonic tissue samples. Similar to the studies described by Salonen et al. [48], we have used a custom-designed gut microbiome specific phylogenetic microarray (the Aus-HIT chip) recently shown to produce a rapid and accurate assessment of gut microbial diversity $[21,36]$.

\section{Materials and Methods}

Human Subject and Tissue Sampling

A colonic tissue sample was obtained from a 73-year-old male subject being examined for colorectal cancer at the 
Queensland Institute for Medical Research, Australia. The colorectum was prepared with $4 \mathrm{~L}$ of Colonlytely PEGbased preparation solution taken orally. The site of tissue resection was clean of any overlying macroscopic adherent fluid or luminal fluid and the tissue was immediately examined post-operatively; with an area of the visually normal mucosa placed in a sterile specimen container and snap frozen in liquid nitrogen. The subject provided informed consent and the use of the tissue was approved by the QIMR ethical board.

\section{Tissue DNA Extraction and Analysis}

The tissue was thawed on ice and then cut into sections ( $\leq 30 \mathrm{mg}$ tissue) with a sterile scalpel, to resemble the size of punch biopsy samples. These tissue samples were subject to one of three methods of DNA extraction typically or historically used by research gastroenterologists with up to seven subsamples processed per method. With the exception of the $\mathrm{RBB}+\mathrm{C}$ samples, the tissue subsections were homogenised using an Ultra Thurax SP4 homogeniser at speed setting 4 until homogenous or for a maximum of 20 s. The QIAGEN AllPrep DNA/RNA Mini Preparation Kit was used as described by the manufacturer's instruction (QIAGEN) with the tissue samples homogenised in $600 \mu \mathrm{l}$ of QIAGEN RLT buffer. The salting out method of DNA extraction followed the methods described by Miller et al. [35] except that a miniprep adapted protocol was followed. A miniprep protocol adapted from the high molecular weight DNA extraction method (HMW method) described by Marmur [30] was also used. Briefly, the tissue subsample was homogenised in $600 \mu \mathrm{l}$ of cell lysis buffer (6 mM Tris- $\mathrm{HCl} \mathrm{pH} \mathrm{8,} 100 \mathrm{mM}$ EDTA, $1 \mathrm{M} \mathrm{NaCl}$ ) and incubated at $75^{\circ} \mathrm{C}$ for $10 \mathrm{~min}$ to inactivate nucleases. Following cooling to ambient temperature, $15 \mu \mathrm{l}$ of lysozyme $(200 \mathrm{mg} / \mathrm{ml}$ stock) and $1.5 \mu \mathrm{l}$ of mutanolysin $(20 \mathrm{U} / \mu \mathrm{l})$ were added and the sample was then incubated at $37^{\circ} \mathrm{C}$ overnight for maximum lysis. Following the incubation, $30 \mu \mathrm{l}$ of $10 \%$ sodium laurylsarcosine and $7.5 \mu \mathrm{l}$ of proteinase $\mathrm{K}(20 \mathrm{mg} / \mathrm{ml})$ were added and the sample was incubated at $55^{\circ} \mathrm{C}$ for $30 \mathrm{~min}$. The sample was extracted with phenol/chloroform/isoamylalcohol (25:24:1) and the residual contaminating phenol/chloroform was subsequently removed by a chloroform/isoamylalcohol (24:1) extraction. The aqueous phase was removed to a fresh microfuge tube and the DNA was precipitated with $3 \mathrm{M}$ sodium acetate $(\mathrm{pH} 5.2)$ and isopropanol. The DNA pellet was washed with $70 \%$ ethanol and the DNA was air dried and resuspended in TE buffer. The fourth method employed was the $\mathrm{RBB}+\mathrm{C}$ method as described by $\mathrm{Yu}$ and Morrison [58]. All of the DNA samples were washed using a Microcon column (Millipore) to remove PCR inhibitors and quantified using a NanoDrop ND-1000. The integrity of the DNA was determined by electrophoresis using a $0.7 \% \mathrm{w} / \mathrm{v}$ agarose gel followed by post-staining using SYBR $^{\circledR}$ Safe DNA gel stain according to the manufacturer's instructions (Invitrogen).

\section{Generation and Fluorescent Labelling of cRNA}

The Bacteria and Archaea rrs genes were PCR amplified using $100 \mathrm{ng}$ of a single DNA sample per extraction method and primers $4 \mathrm{Fa}, 27 \mathrm{~F}$ and 1492-T7R (Table 1). The PCR reactions were performed in triplicate and pooled to reduce the effect of amplification biases. The PCR master mix included $200 \mathrm{nM}$ of each primer, $200 \mu \mathrm{M}$ of each deoxyribonucleotide, $1 \times$ PCR buffer, $3 \mathrm{mM} \mathrm{MgCl}{ }_{2}$ and 0.5 U Native Taq DNA polymerase (Invitrogen). The PCR reaction was initiated by incubating the mixtures at $95^{\circ} \mathrm{C}$ for $5 \mathrm{~min}$, and followed by 30 cycles of $94^{\circ} \mathrm{C}$ for $30 \mathrm{~s}, 58^{\circ} \mathrm{C}$ for $30 \mathrm{~s}$ and $72^{\circ} \mathrm{C}$ for $90 \mathrm{~s}$ and 1 cycle of $72^{\circ} \mathrm{C}$ for $5 \mathrm{~min}$. To eliminate any aberrant amplicons that can be produced by primers $27 \mathrm{~F}$ and $1492 \mathrm{R}$ during $\mathrm{PCR}$, as shown by Osborne et al. [40], all of the PCR reactions were subjected to agarose gel electrophoresis and the $r r s$ amplicons $(\sim 1.5 \mathrm{~kb})$ were gel extracted using a QIAGEN Minelute kit. As an internal standard, the mitochondrial rrs gene was PCR amplified using human DNA as the template and primers MitoF and MitoR-T7 (Table 1). The PCR conditions were the same as those described above except that the elongation step was performed at $72^{\circ} \mathrm{C}$ for $30 \mathrm{~s}$. Where necessary, the samples were concentrated using Pellet Paint Co-Precipitant (Novagen) as directed by the manufacturer.

The gel extracted $r r s$ amplicons were quantified using a NanoDrop ND-1000, and then $500 \mathrm{ng}$ aliquots of the DNA were used as the template for the in vitro synthesis of single-stranded RNA (cRNA). We chose to produce cRNA for hybridization to the microarray because Palmer et al. [43] had previously reported that cRNA allowed significantly enhanced hybridisation specificity, in comparison to the use of dsDNA. The cRNA was produced using the MEGAScript $\mathrm{T} 7$ in vitro transcription kit (Ambion) and purified using the MEGAclear kit (Ambion) as described by Kang et al. [21].

cRNA Labelling, Microarray Hybridization and Image Capture

The Aus-HIT chip and associated methods are described in detail by Kang et al. [21] and the relevant microarray probe and other methodological details, together with the hybridisation results, are also accessible at the GEO database (http://www.ncbi.nlm.nih.gov/geo/; GPL9353 and GSE18420 respectively). In brief detail, $500 \mathrm{ng}$ of the $r r s$ cRNA sample was mixed with $7 \mathrm{ng}$ of mitochondrial cRNA (as an internal standard) and fragmented and labelled using 
Table 1 Primers used in this study

\begin{tabular}{|c|c|c|c|c|}
\hline $\begin{array}{l}\text { Primer } \\
\text { name }\end{array}$ & Primer target(s) & Primer sequence $5^{\prime}-3^{\prime}$ & $\begin{array}{l}\text { Approximate } \\
\text { amplicon size }\end{array}$ & Reference \\
\hline $4 \mathrm{Fa}$ & $\begin{array}{l}\text { Universal } r r s \text { primer } \\
\text { (archaea) }\end{array}$ & TCCCGGTTGATCCTGCCRG & - & [19] \\
\hline $27 \mathrm{~F}$ & $\begin{array}{l}\text { Universal } r r s \text { primer } \\
\text { (bacteria) }\end{array}$ & AGAGTTTGATCMTGGCTCAG & - & {$[24]$} \\
\hline $1492-\mathrm{T}^{\mathrm{a}} \mathrm{R}^{\mathrm{a}}$ & $\begin{array}{l}\text { Universal } r r s \text { primer } \\
\text { (bacteria/archaea) }\end{array}$ & TCTAATACGACTCACTATAGGGGGYTACCTTGTTACGACTT & - & [24] \\
\hline MitoF & Human mitochondrial & TACTACCAGACAACCTTAGC & - & {$[21]$} \\
\hline MitoR-T7 ${ }^{\mathrm{a}}$ & specific $r r s$ primer & TCTAATACGACTCACTATAGGGGTTTCGGGGGTCTTAGCTTT & - & \\
\hline $\begin{array}{l}\text { AllBac296f } \\
\text { AllBac412r }\end{array}$ & $\begin{array}{l}\text { Bacteroides spp. specific } \\
\text { rrs primer }\end{array}$ & $\begin{array}{l}\text { GAGAGGAAGGTCCCCCAC } \\
\text { CGCTACTTGGCTGGTTCAG }\end{array}$ & $106 \mathrm{bp}^{\mathrm{b}}$ & {$[26]$} \\
\hline $\begin{array}{l}\text { PreGen4F } \\
\text { PreGen4R }\end{array}$ & $\begin{array}{l}\text { Prevotella spp. specific } r r s \\
\text { primer }\end{array}$ & $\begin{array}{l}\text { GGTTCTGAGAGGAAGGTCCCC } \\
\text { TCCTGCACGCTACTTGGCTG }\end{array}$ & $121 \mathrm{bp}$ & {$[52]$} \\
\hline $\begin{array}{l}\text { StrepGenF } \\
\text { StrepGenR }\end{array}$ & $\begin{array}{l}\text { Streptococcus spp. specific } \\
\text { rrs primer }\end{array}$ & $\begin{array}{l}\text { CGACGATACATAGCCGACCTGAG } \\
\text { TCCATTGCCGAAGATTCCCTACTG }\end{array}$ & $102 \mathrm{bp}$ & [9] \\
\hline $\begin{array}{l}\text { g-Ccoc-F } \\
\text { g-Ccoc- } R\end{array}$ & $\begin{array}{l}\text { Clostridium coccoides } \\
\text { group specific } r r s \text { primer }\end{array}$ & $\begin{array}{l}\text { AAATGACGGTACCTGACTAA } \\
\text { CTTTGAGTTTCATTCTTGCGAA }\end{array}$ & $440 \mathrm{bp}$ & [31] \\
\hline $\begin{array}{l}1114 \mathrm{~F} \\
1221 \mathrm{R}\end{array}$ & $\begin{array}{l}\text { Universal rrs primer } \\
\text { (bacteria) }\end{array}$ & $\begin{array}{l}\text { CGGCAACGAGCGCAACCC } \\
\text { CCATTGTAGCACGTGTGTAGCC }\end{array}$ & $130 \mathrm{bp}$ & {$[11]$} \\
\hline $\begin{array}{l}\beta \text {-act-F } \\
\beta \text {-act-R }\end{array}$ & $\beta$-actin specific primer & $\begin{array}{l}\text { CCTCGCCTTTGCCGA } \\
\text { TGGTGCCTGGGGCG }\end{array}$ & $171 \mathrm{bp}$ & {$[3]$} \\
\hline
\end{tabular}

${ }^{\mathrm{a}}$ The $1492 \mathrm{R}$ and Mito-R based primers were modified to include a T7 promoter sequence (italicised)

${ }^{\mathrm{b}}$ Base pairs

the Label IT $\mu$ Array Cy5 labelling kit (Mirus) following the manufacturer's specifications. Four replicate hybridisations were performed for each labelled cRNA sample, and the microarray slides were scanned using an Axon Genepix 4000A microarray scanner (Axon Instruments, Union City, CA, USA). The images obtained were analysed using GenePix Pro 6.0 software (Axon Instruments) and probe signal intensities were quantified as the difference between foreground and background intensities at $635 \mathrm{~nm}$.

\section{Data Processing and Analysis}

The raw signal data was processed using the Genespring GX10 software (Agilent Technologies) and the three hybridisation profiles showing the most even intensity distributions for each extraction method were selected for normalisation. Intensity values were transformed to $\log 2$, normalised using the quantile normalisation method and probes not giving higher intensities than the negative controls in at least all replicates of one extraction method were discarded. The profiles obtained were then analysed with a multivariate method derived from numerical ecology: between group analysis (BGA) applied to correspondence analysis [10, 15], using the R package ade4 [12]. A Monte Carlo permutation test was performed to assess the significance of the constraint being evaluated. Moreover, the stability of gene contributions to the modelled constraint was assessed using the multistab package [4]. Only stable probes $(p<0.05)$ with a greater contribution to the models than the spiked controls were considered as being affected by extraction method.

\section{Real-Time PCR Analysis}

Quantitative real-time PCR reactions were performed using five independent DNA samples prepared using each of the four methods described above $(n=20)$. A dilution series of the template DNA was constructed and used to identify non-specific amplification and to calculate amplification efficiency using the primer sets described in Table 1. Each PCR reaction mixture contained $10 \mathrm{ng}$ of DNA template, $200 \mathrm{nM}$ of each primer and $1 \mathrm{X}$ iQ SYBR Green Supermix (BioRad). Each reaction was dispensed, in quadruplicate, into $5 \mu \mathrm{l}$ aliquots in a 384-well plate using a Biomek 2000 automated workstation (Beckman). The real-time PCR reactions were performed using a $7900 \mathrm{HT}$ sequence detection system (Applied Biosystems) and the following conditions: one cycle of $95^{\circ} \mathrm{C}$ for $10 \mathrm{~min}, 40$ cycles of $95^{\circ} \mathrm{C}$ for $15 \mathrm{~s}$ and $58^{\circ} \mathrm{C}$ for $30 \mathrm{~s}$ followed by a dissociation curve cycle of $95^{\circ} \mathrm{C}$ for $15 \mathrm{~s}, 60^{\circ} \mathrm{C}$ for $15 \mathrm{~s}$ and $95^{\circ} \mathrm{C}$ for $15 \mathrm{~s}$. Individual reactions showing aberrant amplification profiles were discarded from further analysis. The data obtained from each individual reaction and the amplification efficiencies derived from the dilution series were used to determine the relative quantification of the various DNA targets. Briefly, the data for each specific microbial group 
was normalised by the Livak method [29] using Bacteriaspecific $r$ rs gene primers (Table 1) as the reference; and differences were expressed with reference to the data obtained using the DNA samples prepared with the QIAGEN AllPrep DNA/RNA kit. The recovery of host (human) DNA was assessed by quantitative real-time PCR targeting the $\beta$-actin gene using specific primers (Table 1).

\section{Results}

Extraction of DNA from Human Colonic Tissue Samples

Three of the four DNA extraction methods produced similar yields of total DNA. The HMW method recovered the most DNA $(1,578.0 \pm 573.6$ ng DNA per mg tissue) followed by the salting out $(1,258.5 \pm 570.7 \mathrm{ng}$ DNA per $\mathrm{mg}$ tissue) and $\mathrm{RBB}+\mathrm{C}(1,129.3 \pm 302.3 \mathrm{ng}$ DNA per mg tissue). However in our hands, the QIAGEN AllPrep DNA/RNA method recovered much less total DNA $(282.7 \pm 201.4 \mathrm{ng}$ DNA per $\mathrm{mg}$ tissue). The A260/A280 ratio of the DNA extractions were all similar (HMW method 1.89 \pm 0.01 ; salting out method $1.83 \pm 0.03$; RBB $+\mathrm{C}$ method $1.89 \pm 0.01$; QIAGEN AllPrep DNA/RNA method $1.84 \pm 0.06$ ) indicating that the preparations were comparably pure. Agarose gel electrophoresis revealed that the majority of the DNA was in a high molecular weight form $(>10 \mathrm{~kb})$ and with no significant shearing observed below $1.5 \mathrm{~kb}$ irrespective of the DNA extraction method used (Fig. 1). Taken together, the results suggest that all four methods provide high quality DNA suitable for downstream processing.

\section{Aus-HIT Chip-Based Characterisation of the Extracted DNA Samples}

We used the Aus-HIT chip to determine the ability of the individual DNA extraction methods to capture the micro-

Figure 1 Characterisation of extracted DNA as determined by agarose gel $(0.7 \%)$ electrophoresis. $a$ QIAGEN AllPrep DNA/RNA Kit; $b$ salting out method; $c$ HMW method; $d \mathrm{RBB}+\mathrm{C}$ method bial diversity associated with the colonic tissue samples. The hybridization profiles were essentially identical, except for a small percentage $(<10 \%)$ of the probes that gave rise to statistically significant differences in signal intensity $(p<$ 0.05 ). These findings suggest that while the efficacy of the four DNA extractions methods examined here are similar, and will produce qualitatively similar profiles of microbial diversity from mucosal DNA samples, there does appear to be some differences between the extraction methods in terms of DNA release.

The microarray hybridization data produced for each DNA extraction method were subjected to a BGA in order to better evaluate these preliminary findings and to further dissect the effect of the individual extraction methods on DNA recovery from different microbial groups. The principal axes of BGA are defined as the linear combination of probes that maximises the between-group variance allowing the identification of groups of probes that discriminate between classes of samples. The results of this analysis are illustrated in Fig. 2a and reveal that the main axis of variation was characterised by a general inverse relationships between several Bacteroidetes and Firmicutes group-specific probes. The analysis revealed that the QIAGEN AllPrep DNA/RNA and salting out methods produced profiles most similar to that of the $\mathrm{RBB}+\mathrm{C}$ method; but when compared to the $\mathrm{RBB}+\mathrm{C}$ method the probe signal intensities for some of the Bacteroides and Prevotella spp. probes were stronger; and weaker for some of the Veillonella and Streptococcus spp.-based probes (Fig. 2b). Interestingly, the profile arising from DNA extracted using the HMW method was separated from the others by the second principal axis, because it provided the strongest signals for a small number of Clostridium-specific probes, as well as Streptococcus spp.-based probes.

We also examined the ability of the individual DNA extraction methods to detect the archaeal diversity associated with the colonic tissue. There were no statistically significant differences in the hybridisation profiles for methanogenic archaea for all four DNA extraction methods tested $(p>0.05)$. Similar to previous studies [14, 42], we detected the presence of Methanobrevibacter smithii with colonic tissue but in addition we also detected the presence of Methanosaeta spp. and Methanocaldococcus spp. None of the DNA extracts produced a detectable signal for Methanosphaera spp. We also observed positive signals for some nonmethanogenic archaea. The DNA extracts produced by the HMW method resulted in significantly stronger hybridization signals for probes targeting the euryarchaeote Halobacterium spp. in contrast to the other three methods ( $p<0.05)$; and the salting out method resulted in a significantly stronger hybridization signals for the crenarchaeote Sulfobus spp. in contrast to the QIAGEN AllPrep DNA/RNA and RBB $+\mathrm{C}$ methods $(p<0.05)$. 


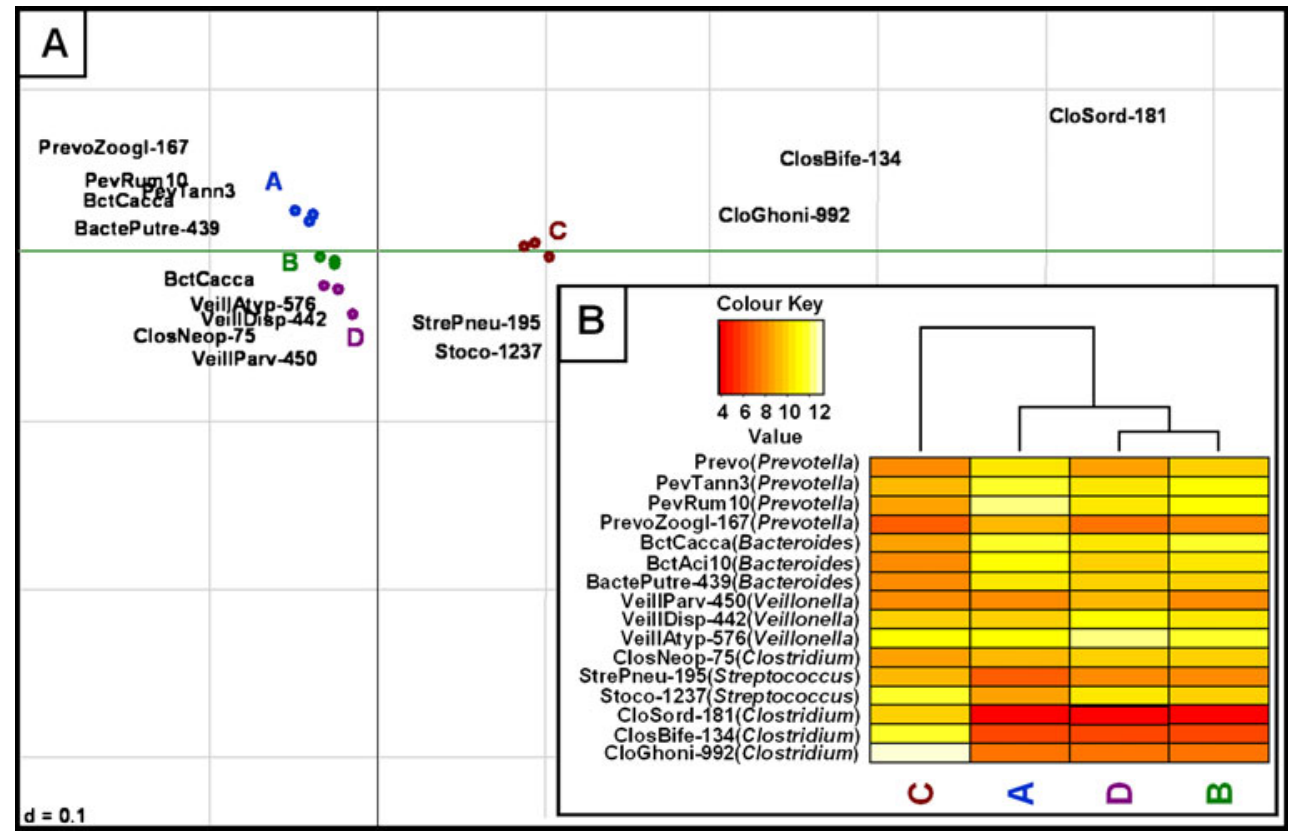

Figure 2 a Discrimination of the microarray profiles derived from the four different DNA extraction methods using BGA applied to correspondence analysis. The most discriminant bacterial probes occurring at least twice at the genus level are plotted and the relative positions of objects (probes and profiles) provide a measure of the strength of their association. The BGA analysis indicated that the different DNA extraction methods employed had a significant effect on the microbial community profiles generated, accounting for most of the variance found $(65.9 \%, p<0.05)$. The axes represent $60.2 \%(X)$ and $5.7 \%(Y)$ of the variation. The three individual hybridisations per DNA extraction method are shown. b Heat map of the probes identified in a with hierarchical clustering based on DNA extraction

\section{Real-Time PCR Analysis of Colonic Tissue-Extracted DNA}

To further evaluate the microarray-based observations, several of the bacterial groups identified by the BGA analysis to be variant with respect to DNA extraction method were subjected to real-time PCR analysis. The realtime PCR analyses confirmed that DNA extracted using the QIAGEN AllPrep DNA/RNA kit and salting out methods do contain a greater relative amount of microbial DNA representing Bacteroides spp. and Prevotella spp. compared to DNA extracted using the HMW and $\mathrm{RBB}+\mathrm{C}$ methods $(p<0.05$, Fig. 3). Similarly, the DNA extracted using the HMW and $\mathrm{RBB}+\mathrm{C}$ methods were found to contain a greater amount of DNA representing Streptococcus spp. and the Clostridium coccoides group $(p<0.05)$, although the difference between the HMW and salting out methods for Streptococcus spp. was marginal $(p<0.07)$. These findings suggest that the variation in probe intensities observed for the microarray data were as a consequence of the DNA extraction method per se, rather than any bias introduced during the PCR amplification of the rrs genes or in the method. a QIAGEN AllPrep DNA/RNA Kit, b salting out method, c HMW method, and $\mathbf{d} \mathrm{RBB}+\mathrm{C}$ method of DNA extraction. The probe names are defined as follows: BctAci10 (Bacteroides acidofaciens); BctCacca (Bacteroides caccae); BactePutre-439 (Bacteroides putredinis); ClosBife-134 (Clostridium bifermentans); CloGhoni-992 (Clostridium ghoni); ClosNeop-75 (Clostridium neopropionicum); CloSord-181 (Clostridium sordellii); PevRum10 (Prevotella ruminicola); Prevo (Prevotella sp.); PevTann3 (Prevotella tannerae); PrevoZoogl-167 (Prevotella zoogleoformans); StrePneu-195 (Streptococcus pneumoniae); Stoco-1237 (Streptococcus sp.); VeillAtyp-576 (Veillonella atypical); VeillDisp-442 (Veillonella dispar); VeillParv450 (Veillonella parvula)

production of cRNA for the microarray analysis. In summation, we interpret these findings as showing that the DNA extraction method used with mucosal tissue does have a subtle impact on the recovery of microbial DNA; with the $\mathrm{RBB}+\mathrm{C}$ and $\mathrm{HMW}$ methods of DNA extraction releasing more DNA from some Firmicutes bacteria.

We also used real-time PCR-targeting the $\beta$-actin gene as a measure of the host DNA recovered by the different extraction methods. Interestingly, the salting out and HMW methods of DNA extraction recovered significantly more host DNA $(p<0.05)$ than the QIAGEN AllPrep DNA/RNA and $\mathrm{RBB}+\mathrm{C}$ methods (Fig. 3). The latter methods use nucleic acid binding columns and it may be that the smaller bacterial chromosomes and/or DNA fragments generated from the homogenisation or bead beating process are able to bind more efficiently to the columns, and are thus enriched. However, despite the greater amounts of "background" host DNA in these samples, the concordance between the real-time PCR and microarray results suggests that the amount of host DNA present did not adversely impact microbial DNA extraction or its amplification. 


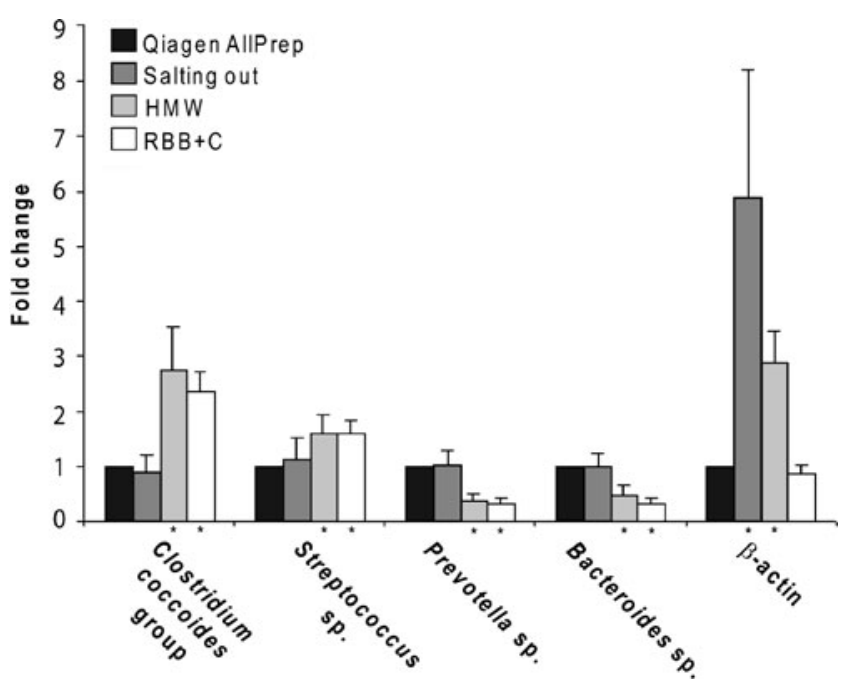

Figure 3 Real-time PCR analysis of resected colonic tissue extracted DNA. Data for each specific group was normalised by the Livak method [29] using Bacteria-specific rrs gene primers [11]; bars represent the average fold change in relation to the QIAGEN AllPrep DNA/RNA sample. Significant differences $(p<0.05)$ between DNA extraction methods identified by real time PCR results targeting specific bacterial groups are annotated by an asterisk although the difference between the HMW and salting-out methods for Streptococci spp. is marginal $(p<0.07)$

\section{Discussion}

The goal of this study was to establish whether the method of DNA extraction used with mucosal tissue samples may impact the recovery and representation of the microbial diversity associated with that tissue. Previous studies have described the effects from various DNA extraction protocols on microbial diversity from stool samples as assessed by DGGE [58, 59], T-RFLP [37] and PCR [33]. Here, we applied the Aus-HIT chip to characterise the effects from different DNA extraction methods on the recoverable microbial diversity associated with colonic tissue.

Our results demonstrate that all four methods of DNA extraction are efficacious in releasing DNA from the microbial populations associated with the colonic tissue; and produce comparably similar profiles of community diversity. Nonetheless, a small percentage of probes were identified that gave statistically significant differences in signal intensity and based on the results presented here, these differences arise because the QIAGEN AllPrep DNA/ RNA and salting out methods were not as efficient as the $\mathrm{HMW}$ or $\mathrm{RBB}+\mathrm{C}$ methods for recovering DNA from some of the Firmicutes like Veillonella, Streptococcus and Clostridium spp. These differences in extraction efficiencies observed are likely due to the mechanism of lysis. Lysis by the QIAGEN AllPrep DNA/RNA or salting out methods are relatively gentle, especially when compared to the extensive enzymatic treatment and chemical based lysis used with the HMW method, and the mechanical- and chemical-based lysis used with the $\mathrm{RBB}+\mathrm{C}$ method. These differences in lysis efficiency are most likely to be observed with bacteria that possess a cell wall ultrastructure that is especially difficult to lyse and/or mechanically disrupt. The differences between the $\mathrm{HMW}$ and $\mathrm{RBB}+\mathrm{C}$ profiles for the Firmicutes-based probes are interesting and assuming that lysis by the $\mathrm{RBB}+\mathrm{C}$ method is relatively non-discriminatory this suggests that the enzymatic based lysis inherent to the HMW method may be prone to bias.

Salonen et al. [48] also reported a higher proportion of Bacteroidetes and a lower proportion of Clostridium cluster XIV and Actinobacteria with DNA recovered from faeces using a QIAGEN Stool DNA Mini kit. The observations by Salonen et al. [48] are consistent with those of other studies (e.g. $[14,22]$ ) and they hypothesised that the QIAGEN Stool DNA Mini kit was able to extract DNA more readily from the Gram-negative population of the human faecal community resulting in an apparent overestimation of their prevalence in the sample. In a separate study characterising the effectiveness of DNA recovery from faecal samples, Wang et al. [56] concluded that DNA was released from Gram-negative bacteria with much higher efficiency (80$100 \%)$ than from Gram-positive bacteria (1-20\%). Other studies have also reported similar variations in DNA extraction efficiency (e.g. [33, 39]) and taken together this further confirms our observation with the Aus-HIT chip that the mechanism of DNA extraction can significantly impact the recovery of microbial diversity leading to differential representation of particular phylogenetic groups.

We found that all four DNA extraction methods were broadly comparable in detecting the archaeal diversity associated with the colonic tissue with only slight variations observed between the methods. The predominant human methanogenic gut archaea, $M$. smithii was detectable by all four extraction methods; however, in contrast Methanosphaera spp. was not detected. Recent studies have revealed that the human colonic methanogenic archaeal community may be more diverse than previously estimated $[16,34,38$, 50] and in addition to $M$. smithii, we also detected Methanosaeta spp. and Methanocaldococcus spp. in association with the tissue sample. Methanosaeta spp. has not previously been associated with human samples; however, it and the broader Methanosaetacae have been detected in anaerobic digesters containing anaerobic sewage sludge or a combination of anaerobic sewage sludge with bovine faecal material as an inoculum [17, 32]. Oxley et al. [42] also identified Methanosaeta spp. rrs gene sequences ( $\geq 99 \%$ similarity) in association with table salt suggesting a possible dietary source for this archaea. In contrast, the Methanococcacae have previously been detected in rumen gastrointestinal environments by probe-based approaches, but these observations remain to be conclusively confirmed 
[20]. Nonetheless, putative Methanococcales and Methanosarcinales DNA sequences were identified in a metagenomic dataset produced from human faecal samples [16]. We also detected non-methanogenic archaea in association with the colonic tissue, in particular Halobacterium spp. and Sulfolobus spp. These and other phylogenetically similar archaea have previously been shown to be associated with human faecal and/or tissue samples [16, 38, 42, 47]. Taken together, this suggests that the archaeal diversity within the human colon may potentially have been significantly underestimated and a deep sequencing approach targeting the human colonic archaea may provide further insight into the phylogenetic diversity and ecophysiological role of this community.

Recent observations suggest that there is a microbial phylogenetic core that is associated with human faecal samples $[44,53]$. In addition, a recent study revealed the presence of a faecal-associated core measurable microbiota in mice; the abundance of which is shaped by both environmental and host genetic factors [5]. The mucosal and faecal associated microbiota have been shown to differ and it remains to be determined if a similar or distinct mucosal associated phylogenetic core exists. It may be that in addition to genetic susceptibility, host-mediated perturbations in the mucosal microbiota also contribute to disease propensity. The Aus-HIT chip, as do the other HIT microarrays, offers a useful tool complementary to next generation sequencing methods for this type of diversity analysis.

\section{Conclusion}

Our results show that while all four methods are equally efficacious at releasing microbial DNA, the HMW and $\mathrm{RBB}+\mathrm{C}$ methods of DNA extraction were more efficient in extracting DNA from some of the Firmicutes bacteria associated with colonic tissue. Importantly, these results also suggest that tissue DNA extracts held in archival biobanks may be amenable to retrospective microbial diversity analyses provided that comparisons are restricted to samples subjected to the same DNA extraction method. The purity of the archived DNA sample(s), the storage temperature and the effects of oxidative damage are also important considerations prior to commencing detailed analyses $[1,25]$.

Acknowledgements This research was funded in part by CSIRO's Preventative Health Flagship Research Program (Colorectal Cancer and Gut Health Theme), CSIRO's Transformational Biology Capability Platform, the OCE Science Leader award (to MM) and the OCE Postdoctoral Fellow program (awarded to EK). We thank Antonio Reverter and Maree O'Sullivan for providing suggestions with the statistical analyses used in this research and also thank Michael Conlon and Sean McWilliam for providing critical reading and suggestions to improve the manuscript. PÓC and DAC contributed equally to this work.

\section{References}

1. Anchordoquy TJ, Molina MC (2007) Preservation of DNA. Cell Preserve Tech 5:180-188

2. Backhed F, Ley RE, Sonnenburg JL, Peterson DA, Gordon JI (2005) Host-bacterial mutualism in the human intestine. Science 307:1915-1920

3. Bas A, Forsberg G, Hammarstrom S, Hammarstrom ML (2004) Utility of the housekeeping genes $18 \mathrm{~S}$ rRNA, b-actin and glyceraldehyde-3-phosphate-dehydrogenase for normalization in real-time quantitative reverse transcriptase-polymerase chain reaction analysis of gene expression in human $\mathrm{T}$ lymphocytes. Scand J Immunol 59:566-573

4. Baty F, Facompre M, Wiegand J, Schwager J, Brutsche MH (2006) Analysis with respect to instrumental variables for the exploration of microarray data structures. BMC Bioinformatics 7:422

5. Benson AK, Kelly SA, Legge R, Ma F, Low SJ, Kim J, Zhang M, Oh PL, Nehrenberg D, Hua K, Kachman SD, Moriyama EN, Walter J, Peterson DA, Pomp D (2010) Individuality in gut microbiota composition is a complex polygenic trait shaped by multiple environmental and host genetic factors. Proc Natl Acad Sci U S A. doi:10.1073/pnas.1007028107

6. Bibiloni R, Mangold M, Madsen KL, Fedorak RN, Tannock GW (2006) The bacteriology of biopsies differs between newly diagnosed, untreated, Crohn's disease and ulcerative colitis patients. J Med Microbiol 55:1141-1149

7. Campieri M, Gionchetti P (2001) Bacteria as the cause of ulcerative colitis. Gut 48:132-135

8. Caporaso JG, Kuczynski J, Stombaugh J, Bittinger K, Bushman FD, Costello EK, Fierer N, Pena AG, Goodrich JK, Gordon JI, Huttley GA, Kelley ST, Knights D, Koenig JE, Ley RE, Lozupone CA, McDonald D, Muegge BD, Pirrung M, Reeder J, Sevinsky JR, Turnbaugh PJ, Walters WA, Widmann J, Yatsunenko T, Zaneveld J, Knight R (2010) QIIME allows analysis of highthroughput community sequencing data. Nat Meth 7:335-336

9. Chalmers NI, Palmer RJ Jr, Cisar JO, Kolenbrander PE (2008) Characterization of a Streptococcus sp.-Veillonella sp. community micromanipulated from dental plaque. J Bacteriol 190:8145-8154

10. Culhane AC, Perriere G, Considine EC, Cotter TG, Higgins DG (2002) Between-group analysis of microarray data. Bioinformatics 18:1600-1608

11. Denman SE, McSweeney CS (2006) Development of a real-time PCR assay for monitoring anaerobic fungal and cellulolytic bacterial populations within the rumen. FEMS Microbiol Ecol 58:572-582

12. Dray S, Dufour A-B (2007) The ade4 package: implementing the duality diagram for ecologists. J Stat Soft 22:1-20

13. Dridi B, Henry M, El Khéchine A, Raoult D, Drancourt M (2009) High prevalence of Methanobrevibacter smithii and Methanosphaera stadtmanae detected in the human gut using an improved DNA detection protocol. PLoS ONE 4:e7063

14. Eckburg PB, Bik EM, Bernstein CN, Purdom E, Dethlefsen L, Sargent M, Gill SR, Nelson KE, Relman DA (2005) Diversity of the human intestinal microbial flora. Science 308:1635-1638

15. Fellenberg K, Hauser NC, Brors B, Neutzner A, Hoheisel JD, Vingron M (2001) Correspondence analysis applied to microarray data. Proc Natl Acad Sci U S A 98:10781-10786

16. Gill SR, Pop M, Deboy RT, Eckburg PB, Turnbaugh PJ, Samuel BS, Gordon JI, Relman DA, Fraser-Liggett CM, Nelson KE (2006) Metagenomic analysis of the human distal gut microbiome. Science 312:1355-1359

17. Griffin ME, McMahon KD, Mackie RI, Raskin L (1998) Methanogenic population dynamics during start-up of anaerobic digesters treating municipal solid waste and biosolids. Biotechnol Bioeng 57:342-355 
18. Guarner F, Malagelada JR (2003) Gut flora in health and disease. Lancet 361:512-519

19. Hershberger KL, Barns SM, Reysenbach A-L, Dawson SC, Pace NR (1996) Wide diversity of Crenarchaeota. Nature 384:420

20. Janssen PH, Kirs M (2008) Structure of the archaeal community of the rumen. Appl Environ Microbiol 74:3619-3625

21. Kang S, Denman SE, Morrison M, Yu Z, Dore J, Leclerc M, McSweeney CS (2010) Dysbiosis of fecal microbiota in Crohn's disease patients as revealed by a custom phylogenetic microarray. Inflamm Bowel Dis. doi:10.1002/ibd.21319

22. Khachatryan ZA, Ktsoyan ZA, Manukyan GP, Kelly D, Ghazaryan KA, Aminov RI (2008) Predominant role of host genetics in controlling the composition of gut microbiota. PLoS ONE 3:e3064

23. Kunin V, Engelbrektson A, Ochman H, Hugenholtz P (2010) Wrinkles in the rare biosphere: pyrosequencing errors can lead to artificial inflation of diversity estimates. Environ Microbiol $12: 118-123$

24. Lane DS (1990) 16 S and 23S rRNA sequencing. In: Stackebrandt E, Goodfellow M (eds) Nucleic acid techniques in bacterial systematics. Wiley, New York, pp 115-148

25. Lauber CL, Zhou N, Gordon JI, Knight R, Fierer N (2010) Effect of storage conditions on the assessment of bacterial community structure in soil and human-associated samples. FEMS Microbiol Lett 307:80-86

26. Layton A, McKay L, Williams D, Garrett V, Gentry R, Sayler G (2006) Development of Bacteroides 16S rRNA gene TaqManbased real-time PCR assays for estimation of total, human, and bovine fecal pollution in water. Appl Environ Microbiol 72:4214 4224

27. Lepage P, Seksik P, Sutren M, de la Cochetiere MF, Jian R, Marteau P, Dore J (2005) Biodiversity of the mucosa-associated microbiota is stable along the distal digestive tract in healthy individuals and patients with IBD. Inflamm Bowel Dis 11:473480

28. Li F, Hullar MA, Lampe JW (2007) Optimization of terminal restriction fragment polymorphism (TRFLP) analysis of human gut microbiota. J Microbiol Methods 68:303-311

29. Livak KJ, Schmittgen TD (2001) Analysis of relative gene expression data using real-time quantitative PCR and the $2^{-\Delta \Delta C T}$ method. Methods 25:402-408

30. Marmur J (1961) A procedure for the isolation of deoxyribonucleic acid from micro-organisms. J Mol Biol 3:208-218

31. Matsuki T, Watanabe K, Fujimoto J, Miyamoto Y, Takada T, Matsumoto K, Oyaizu H, Tanaka R (2002) Development of 16S rRNA-gene-targeted group-specific primers for the detection and identification of predominant bacteria in human feces. Appl Environ Microbiol 68:5445-5451

32. McMahon KD, Zheng D, Stams AJM, Mackie RI, Raskin L (2004) Microbial population dynamics during start-up and overload conditions of anaerobic digesters treating municipal solid waste and sewage sludge. Biotechnol Bioeng 87:823-834

33. McOrist AL, Jackson M, Bird AR (2002) A comparison of five methods for extraction of bacterial DNA from human faecal samples. J Microbiol Methods 50:131-139

34. Mihajlovski A, Alric M, Brugère J-F (2008) A putative new order of methanogenic Archaea inhabiting the human gut, as revealed by molecular analyses of the mcrA gene. Res Microbiol 159:516521

35. Miller SA, Dykes DD, Polesky HF (1988) A simple salting out procedure for extracting DNA from human nucleated cells. Nucleic Acids Res 16:1215

36. Mondot S, Kang S, Furet J, Aguirre de Carcer D, McSweeney C, Morrison M, Marteau P, Doré J, Leclerc M (2010) Highlighting new phylogenetic specificities of Crohn's disease microbiota. Inflamm Bowel Dis. doi:10.1002/ibd.21436
37. Nagashima K, Hisada T, Sato M, Mochizuki J (2003) Application of new primer-enzyme combinations to terminal restriction fragment length polymorphism profiling of bacterial populations in human feces. Appl Environ Microbiol 69:1251-1262

38. Nam YD, Chang HW, Kim KH, Roh SW, Kim MS, Jung MJ, Lee SW, Kim JY, Yoon JH, Bae JW (2008) Bacterial, archaeal, and eukaryal diversity in the intestines of Korean people. J Microbiol 46:491-501

39. Nechvatal JM, Ram JL, Basson MD, Namprachan P, Niec SR, Badsha KZ, Matherly LH, Majumdar AP, Kato I (2008) Fecal collection, ambient preservation, and DNA extraction for PCR amplification of bacterial and human markers from human feces. J Microbiol Methods 72:124-132

40. Osborne CA, Galic M, Sangwan P, Janssen PH (2005) PCRgenerated artefact from $16 \mathrm{~S}$ rRNA gene-specific primers. FEMS Microbiol Lett 248:183-187

41. Ott SJ, Musfeldt M, Timmis KN, Hampe J, Wenderoth DF, Schreiber S (2004) In vitro alterations of intestinal bacterial microbiota in fecal samples during storage. Diagn Microbiol Infect Dis 50:237-245

42. Oxley APA, Lanfranconi MP, Würdemann D, Ott S, Schreiber S, McGenity TJ, Timmis KN, Nogales B (2010) Halophilic archaea in the human intestinal mucosa. Environ Microbiol 12:2398-2410

43. Palmer C, Bik EM, Eisen MB, Eckburg PB, Sana TR, Wolber PK, Relman DA, Brown PO (2006) Rapid quantitative profiling of complex microbial populations. Nucleic Acids Res 34:e5

44. Qin J, Li R, Raes J, Arumugam M, Burgdorf KS, Manichanh C, Nielsen T, Pons N, Levenez F, Yamada T, Mende DR, Li J, Xu J, Li S, Li D, Cao J, Wang B, Liang H, Zheng H, Xie Y, Tap J, Lepage P, Bertalan M, Batto JM, Hansen T, Le Paslier D, Linneberg A, Nielsen HB, Pelletier E, Renault P, Sicheritz-Ponten T, Turner K, Zhu H, Yu C, Li S, Jian M, Zhou Y, Li Y, Zhang X, Li S, Qin N, Yang H, Wang J, Brunak S, Dore J, Guarner F, Kristiansen K, Pedersen O, Parkhill J, Weissenbach J, Bork P, Ehrlich SD, Wang J (2010) A human gut microbial gene catalogue established by metagenomic sequencing. Nature 464:59-65

45. Quince C, Lanzen A, Curtis TP, Davenport RJ, Hall N, Head IM, Read LF, Sloan WT (2009) Accurate determination of microbial diversity from 454 pyrosequencing data. Nat Methods 6:639-641

46. Reeder J, Knight R (2010) Rapidly denoising pyrosequencing amplicon reads by exploiting rank-abundance distributions. Nat Methods 7:668-669

47. Rieu-Lesme F, Delbes C, Sollelis L (2005) Recovery of partial $16 \mathrm{~S}$ rDNA sequences suggests the presence of Crenarchaeota in the human digestive ecosystem. Curr Microbiol 51:317-321

48. Salonen A, Nikkilä J, Jalanka-Tuovinen J, Immonen O, RajilicStojanovic M, Kekkonen RA, Palva A, de Vos WM (2010) Comparative analysis of fecal DNA extraction methods with phylogenetic microarray: effective recovery of bacterial and archaeal DNA using mechanical cell lysis. J Microbiol Methods $81: 127-134$

49. Scanlan PD, Shanahan F, Clune Y, Collins JK, O'Sullivan GC, O'Riordan M, Holmes E, Wang Y, Marchesi JR (2008) Cultureindependent analysis of the gut microbiota in colorectal cancer and polyposis. Environ Microbiol 10:789-798

50. Scanlan PD, Shanahan F, Marchesi JR (2008) Human methanogen diversity and incidence in healthy and diseased colonic groups using mcrA gene analysis. BMC Microbiol 8:79

51. Schloss PD, Westcott SL, Ryabin T, Hall JR, Hartmann M, Hollister EB, Lesniewski RA, Oakley BB, Parks DH, Robinson CJ, Sahl JW, Stres B, Thallinger GG, Van Horn DJ, Weber CF (2009) Introducing mothur: open-source, platform-independent, community-supported software for describing and comparing microbial communities. Appl Environ Microbiol 75:7537-7541

52. Stevenson DM, Weimer PJ (2007) Dominance of Prevotella and low abundance of classical ruminal bacterial species in the bovine 
rumen revealed by relative quantification real-time PCR. Appl Microbiol Biotechnol 75:165-174

53. Tap J, Mondot S, Levenez F, Pelletier E, Caron C, Furet J-P, Ugarte E, Muñoz-Tamayo R, Paslier DLE, Nalin R, Dore J, Leclerc M (2009) Towards the human intestinal microbiota phylogenetic core. Environ Microbiol 11:2574-2584

54. Turnbaugh PJ, Hamady M, Yatsunenko T, Cantarel BL, Duncan A, Ley RE, Sogin ML, Jones WJ, Roe BA, Affourtit JP, Egholm M, Henrissat B, Heath AC, Knight R, Gordon JI (2009) A core gut microbiome in obese and lean twins. Nature 457:480-484

55. Turnbaugh PJ, Ley RE, Mahowald MA, Magrini V, Mardis ER, Gordon JI (2006) An obesity-associated gut microbiome with increased capacity for energy harvest. Nature 444:1027-1031

56. Wang RF, Beggs ML, Erickson BD, Cerniglia CE (2004) DNA microarray analysis of predominant human intestinal bacteria in fecal samples. Mol Cell Probes 18:223-234
57. Willing B, Halfvarson J, Dicksved J, Rosenquist M, Jarnerot G, Engstrand L, Tysk C, Jansson JK (2009) Twin studies reveal specific imbalances in the mucosa-associated microbiota of patients with ileal Crohn's disease. Inflamm Bowel Dis 15:653-660

58. Yu Z, Morrison M (2004) Improved extraction of PCR-quality community DNA from digesta and fecal samples. Biotechniques $36: 808-812$

59. Zoetendal EG, Ben-Amor K, Akkermans AD, Abee T, de Vos WM (2001) DNA isolation protocols affect the detection limit of PCR approaches of bacteria in samples from the human gastrointestinal tract. Syst Appl Microbiol 24:405-410

60. Zoetendal EG, von Wright A, Vilpponen-Salmela T, Ben-Amor K, Akkermans AD, de Vos WM (2002) Mucosa-associated bacteria in the human gastrointestinal tract are uniformly distributed along the colon and differ from the community recovered from feces. Appl Environ Microbiol 68:3401-3407 